\title{
A Retrospective Study of the Treatment Results \& Patterns of Failure of Type II Endometrial Cancer Patients Treated at Radiotherapy Department, NCI, Cairo University during the Period from January 2000 till December 2012
}

\author{
Mohamed Serag1, Mohamed Mahmoud ${ }^{1}$, Ahmed Seleem², Mervat Elnagar1 \\ ${ }^{1}$ Radiation Oncology department, National Cancer Institute, Cairo University, Giza, Egypt \\ ${ }^{2}$ Clinical Oncology Department, Faculty of Medicine, Cairo University, Giza, Egypt \\ Email: *M_mahmoud1973@hotmail.com
}

Received 2 July 2016; accepted 19 August 2016; published 22 August 2016

Copyright (C) 2016 by authors and Scientific Research Publishing Inc.

This work is licensed under the Creative Commons Attribution International License (CC BY).

http://creativecommons.org/licenses/by/4.0/

(c) (i) Open Access

\begin{abstract}
Aim of the study: To identify all clinico-pathological data, different treatment modalities and the different prognostic factors which affected the locoregional control (LC), disease-free survival (DFS), and overall survival (OS) of Type II endometrial cancer patients. Patients and methods: Data of Type II endometrial carcinoma patients who presented to the Radiation Oncology department, National Cancer Institute, Cairo University during the period from (2000-2012) were retrospectively reviewed. Results: Multivariate analysis identified stage as an independent prognostic factor for OS \& DFS, and age was an independent prognostic factor for DFS and LC. Low pretreatment hemoglobin levels significantly affected OS. Conclusion: Large and multicentric clinical trials are required to further study this group of patients and define optimum treatment modalities.
\end{abstract}

\section{Keywords}

Endometrial Carcinoma, Radiotherapy, Chemotherapy

\footnotetext{
"Corresponding author.

How to cite this paper: Serag, M., Mahmoud, M., Seleem, A. and Elnagar, M. (2016) A Retrospective Study of the Treatment Results \& Patterns of Failure of Type II Endometrial Cancer Patients Treated at Radiotherapy Department, $\mathrm{NCl}$, Cairo University during the Period from January 2000 till December 2012. Journal of Cancer Therapy, 7, 600-608. http://dx.doi.org/10.4236/jct.2016.78063
} 


\section{Introduction}

Endometrial cancer is the sixth most common cancer in women worldwide \& one of the most frequently occurring female genital cancers, with 320,000 new cases diagnosed in 2012 [1].

Type II Endometrial cancer accounts for 10 to 20 percent of endometrial carcinomas. These include tumors of non-endometrioid histology: serous, clear cell, squamous, transitional cell, and undifferentiated. Uterine carcinosarcomas are also included in this subtype [2].

While the incidence of Type II tumors is low compared to Type I, excess mortality is associated with Type II EC. In an analysis of Surveillance, Epidemiology and End Results (SEER) data, Hamilton et al. [3] reported that while $11 \%$ of ECs were Type II, $47 \%$ of deaths in the SEER cohort occurred in this subtype. Furthermore, stage-adjusted 5-year overall survival rates for Type II tumors are significantly worse compared to Type I tumors [4].

The epidemiology and biology of Type II tumors are not well characterized, although a few studies report that Type II cases are more likely to be older, of normal weight, multiparous, and African American compared to Type I cases [5]-[12]. The tumorigenesis of Type II EC is not thought to operate through the estrogen pathway, as normal-weight and parous women have decreased estrogen exposure compared to obese and nulliparous women. Low incidence of Type II tumors makes this subtype difficult to study.

The proposed aim of this work is to study the clinical and pathological characteristics of Type II endometrial carcinoma patients. Analyze the potential prognostic factors affecting Locoregional Control, Disease-Free Survival and Overall Survival.

\section{Patients and Methods}

This is a retrospective study involving 91 patients with pathoologically proven Type II endometrial carcinoma, who presented to the Radiation Oncology department at the National Cancer Institute, Cairo University during the period from January 2000 to December 2012.

Data was retrieved from the patients' medical records. The collected data included the patients' names, age, menopausal status, comorbidities, obstetric history, performance status, pretreatment hemoglobin levels, presenting symptom(s), pathological subtype, FIGO stage, grade, date and type of surgery, details of adjuvant treatment and response to treatment, side effects and complications of treatment, follow-up details and patterns of failure, salvage treatment and patient status at last follow up.

Patients received external beam radiotherapy 50 Gy/5weeks, 49 patients received brachytherapy (3 patients received Low dose rate to a dose of $30 \mathrm{~Gy}$ and 46 patients received High dose rate brachytherapy $7 \mathrm{~Gy} \times 2$ fractions).

\section{Statistical Analysis}

Statistical Package for Social Sciences (SPSS) version 21 was used. Quantitative data were presented as mean, standard deviation, median and range as appropriate. Qualitative data were presented as frequency and percentage. Survival analysis was done using Kaplan-Meier method. Comparison between two survival curves was done using log-rank test. Cox regression was used for analysis of independent variables affecting survival. P value $\leq 0.05$ was considered significant.

\section{Results}

This is a retrospective study which was done on patients with Type II endometrial carcinoma who were treated at the Radiation Oncology department, National Cancer Institute, Cairo University during the period between year 2000 and 2012 and included a total of 91 patients (Table 1).

Univariate analysis showed patients below 60 years of age had significantly fewer rates of locoregional failure compared to those above 60 years of age (local control rates were $85.7 \%$ at 5 years versus $52.5 \%$ ) ( $\mathrm{p}$ value $=$ 0.026). On multivariate analysis, age was found to be an independent prognostic factor for local control ( $\mathrm{HR}=$ $4.26,95 \% \mathrm{CI}=1.27-14.26)(\mathrm{p}$ value $=0.019)$. Where as for other factors no significant differences were found regarding their impact on local control (Figure 1 and Table 2).

\subsection{Disease Free Survival}

Univaritae analysis showed there is significant improvement in disease free survival for patients less than 60 years 
Table 1. Local control and different prognostic factors.

\begin{tabular}{|c|c|c|c|c|}
\hline Factors & Number of patients & Local control at 3 years (\%) & Local control at 5 years (\%) & $P$ value (univariate) \\
\hline \multicolumn{5}{|l|}{ Age (years) } \\
\hline$<60$ & 32 & 85.7 & 85.7 & 0.026 \\
\hline$\geq 60$ & 56 & 64.1 & 52.5 & \\
\hline \multicolumn{5}{|c|}{ Pretreatment Hemoglobin } \\
\hline$<12 \mathrm{~g} / \mathrm{dl}$ & 29 & 50.6 & 38.0 & 0.114 \\
\hline$\geq 12 \mathrm{~g} / \mathrm{dl}$ & 17 & 87.5 & 72.9 & \\
\hline \multicolumn{5}{|l|}{ Pathology } \\
\hline Papillary Serous & 28 & 71.9 & 61.6 & \\
\hline Clear cell & 12 & 85.7 & 85.7 & 0.140 \\
\hline Undifferentiated & 8 & All cases censored & All cases censored & \\
\hline Carcinosarcoma & 40 & 57.0 & 42.7 & \\
\hline \multicolumn{5}{|l|}{ Lymph nodes } \\
\hline $\mathrm{Nx}$ & 63 & 74.8 & 60.1 & 0880 \\
\hline N0 & 18 & 69.2 & 69.2 & 0.000 \\
\hline N1 & 7 & All cases censored & All cases censored & \\
\hline \multicolumn{5}{|l|}{ FIGO stage } \\
\hline Early (I,II) & 68 & 75.9 & 59.6 & 0.841 \\
\hline Advanced (III,IV) & 20 & 78.1 & 78.1 & \\
\hline \multicolumn{5}{|l|}{ Adjuvant ERBT } \\
\hline No & 9 & 57.1 & 38.1 & 0.111 \\
\hline Yes & 79 & 79.6 & 70.5 & \\
\hline \multicolumn{5}{|l|}{ Brachytherapy } \\
\hline Yes & 49 & 85.7 & 78.6 & 0.075 \\
\hline No & 39 & 66.3 & 49.8 & \\
\hline \multicolumn{5}{|l|}{ Chemotherapy } \\
\hline Yes & 8 & 64.3 & 64.3 & 0.919 \\
\hline No & 78 & 77.1 & 63.5 & \\
\hline
\end{tabular}

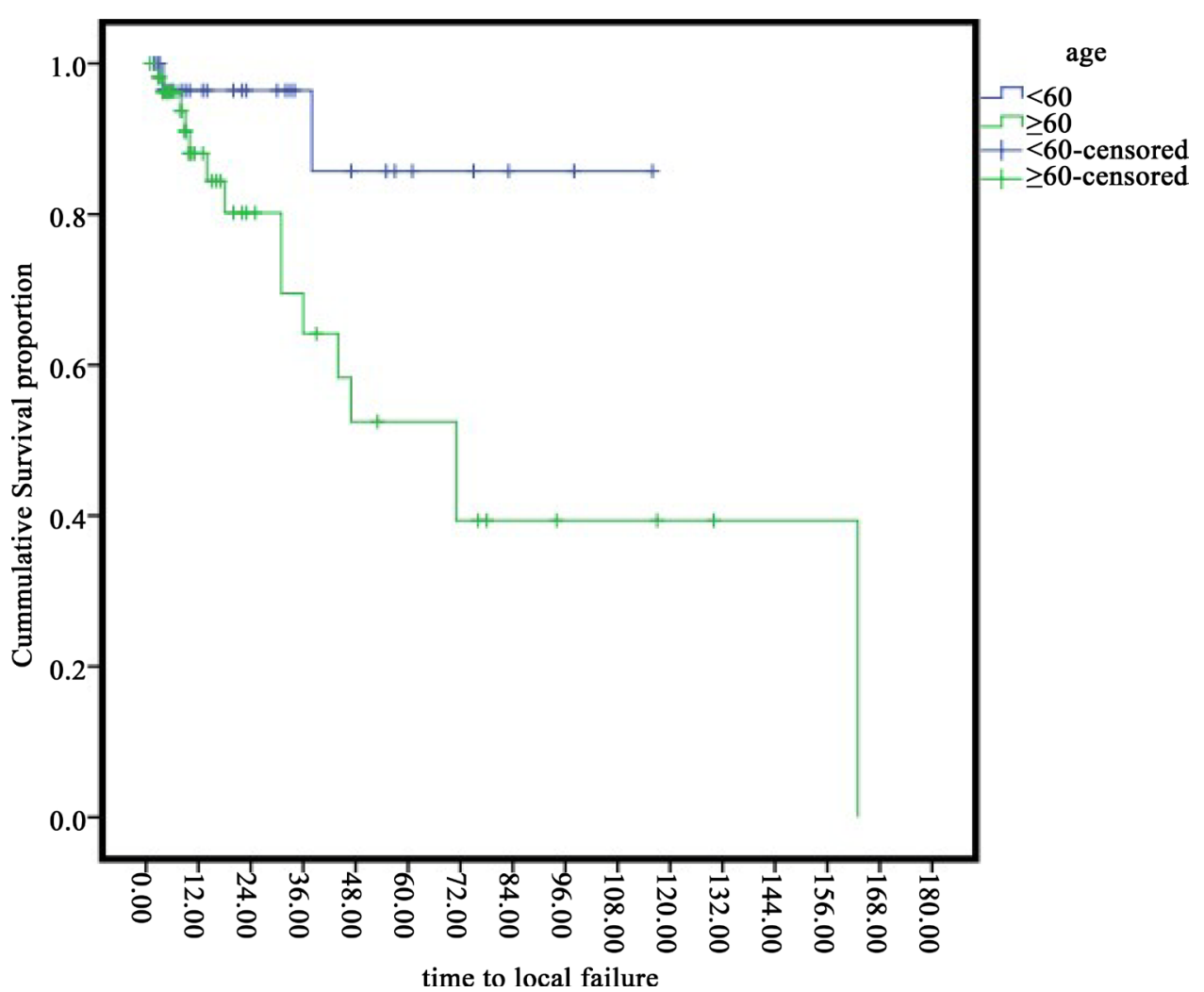

Figure 1. Impact of age on local control. 
Table 2. Disease free survival and different prognostic factors.

\begin{tabular}{|c|c|c|c|c|c|}
\hline Factors & No. of patients & 3 DFS \% & 5 years DFS & P value (univariate) & P value (multivariate) \\
\hline \multicolumn{6}{|l|}{ Age (years) } \\
\hline$<60$ & 32 & 84.5 & 65.7 & 0.001 & 0.005 \\
\hline$\geq 60$ & 56 & 41.1 & 32.4 & & \\
\hline \multicolumn{6}{|c|}{ Pretreatment Hemoglobin } \\
\hline$<12 \mathrm{~g} / \mathrm{dl}$ & 29 & 43.4 & 32.5 & 0.117 & \\
\hline$\geq 12 \mathrm{~g} / \mathrm{dl}$ & 17 & 65.7 & 52.5 & & \\
\hline \multicolumn{6}{|l|}{ Pathology } \\
\hline Papillary Serous & 29 & 44.2 & 44.2 & & \\
\hline Clear Cell & 12 & 72.9 & 72.9 & 0.666 & \\
\hline Undifferentiated & 8 & 68.6 & 51.4 & & \\
\hline Carcinosarcoma & 39 & 60.6 & 26.9 & & \\
\hline \multicolumn{6}{|l|}{ Lymph nodes } \\
\hline $\mathrm{Nx}$ & 64 & 52.1 & 41.4 & & \\
\hline No & 17 & 94.1 & 70.6 & 0.089 & \\
\hline $\mathrm{N}+$ & 7 & 41.7 & 0 & & \\
\hline \multicolumn{6}{|l|}{ FIGO stage } \\
\hline Early (I,II) & 68 & 62.7 & 52.0 & $<0.001$ & 0.026 \\
\hline Late (III,IV) & 20 & 0 & 0 & & \\
\hline \multicolumn{6}{|l|}{ ERBT } \\
\hline No & 8 & 38.1 & 38.1 & 0.694 & \\
\hline Yes & 80 & 59.0 & 44.9 & & \\
\hline \multicolumn{6}{|l|}{ Brachytherapy } \\
\hline Yes & 49 & 70.9 & 57.3 & 0.004 & 0.011 \\
\hline No & 39 & 40.5 & 27.0 & & \\
\hline \multicolumn{6}{|l|}{ Chemotherapy } \\
\hline Yes & 8 & 72.9 & 72.9 & & \\
\hline No & 78 & 54.3 & 41.2 & 0.273 & \\
\hline Factors & No. of patients & 3 DFS \% & 5 years DFS & $P$ value (univariate) & $P$ value (multivariate) \\
\hline \multicolumn{6}{|c|}{ Duration from surgery to ERBT } \\
\hline$\leq 2$ months & 48 & 59.2 & 50.1 & 0.866 & \\
\hline$>2$ months & 32 & 59.1 & 29.6 & & \\
\hline
\end{tabular}

with $\mathrm{p}=0.001$, for patients with early stages there was better DFS with significant $\mathrm{P}=0.001$, also those who received brachyjtherapy they had better DFS with $\mathrm{p}=0.004$ (Figures 2-4 and Table 3).

\subsection{Overall Survival}

Univariate analysis showed better overall survival for patients less than 60 years old with $p=0.002$, also patients with stage I and II disease had better overall survival than advanced stage with $p=0.004$ (Figure 5 \& Figure 6).

\section{Discussion}

Our study confirmed that age was a significant prognostic factor; advanced age ( $>60$ years) was associated with worse local control $(p=0.026)$, disease-free survival $(p=0.001)$ and overall survival $(p=0.02)$. This is consistent with numerous studies, such as that conducted by Vance et al. to determine the prognostic significance of age in type II endometrial carcinomas in general which found that age more than 65 years is a significant adverse prognostic factor for tumor recurrence [13].

According to the FIGO 26th annual report, FIGO stage was a significant prognostic factor for survival. 5-year OS rates for stage I disease was $90 \%$ for endometrioid carcinoma and $80 \%$ - 85\% type II histologies, and dropped to $29 \%$ for stage IV disease [14]. Similarly, in our study patients with advanced stage disease had significantly lower rates of DFS ( $\mathrm{p} \leq 0.001)$ and OS $(\mathrm{p}=0.004)$.

Previous studies conducted to evaluate the effect of adding brachytherapy to EBRT concluded that it did not confer additional benefit to local control or overall survival [15]. However, in a study by Sorbe et al., the combination of brachytherapy and EBRT led to significant improvement in LC without OS benefit [16]. Most of the 


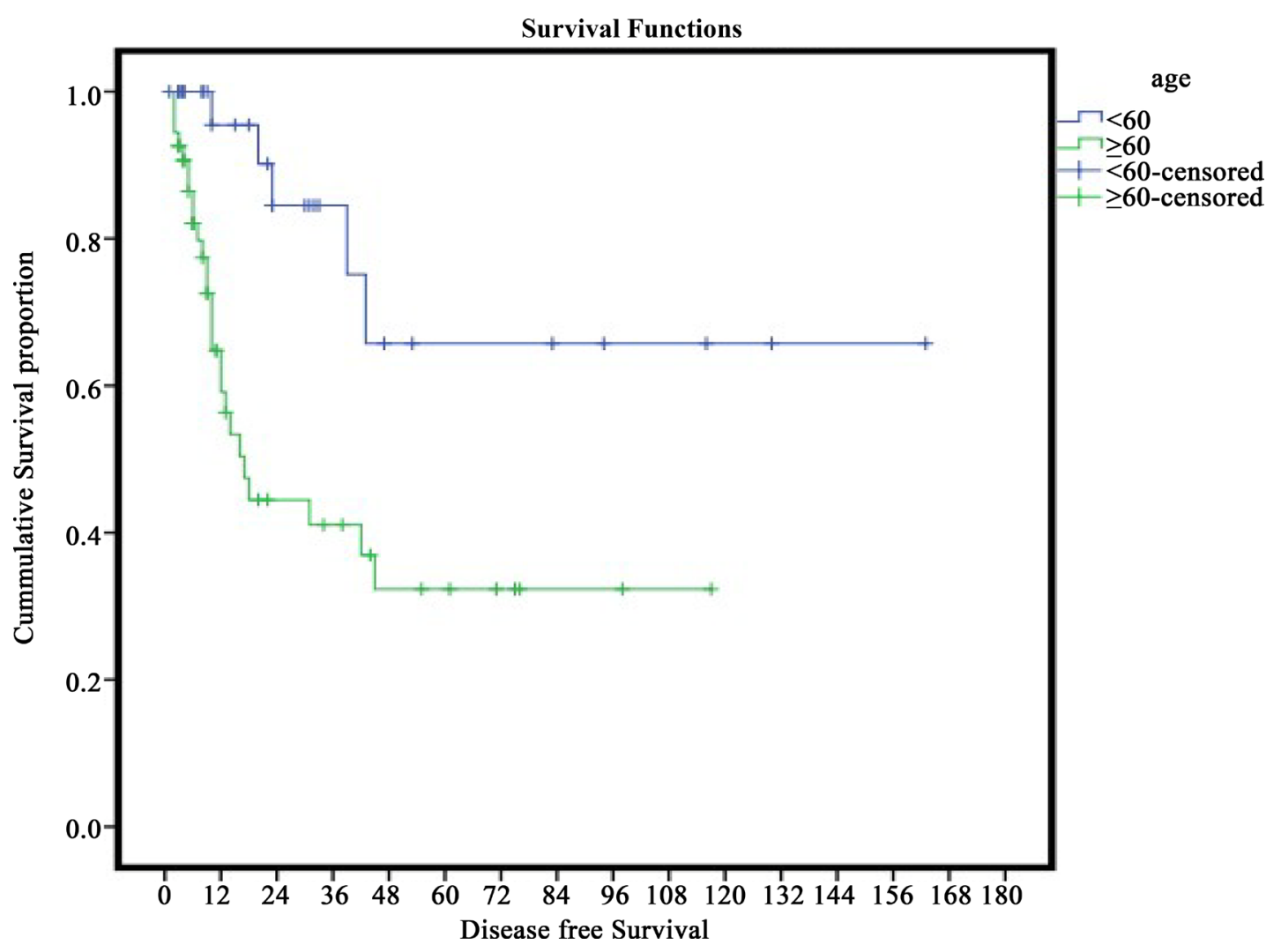

Figure 2. Impact of age on disease free survival.

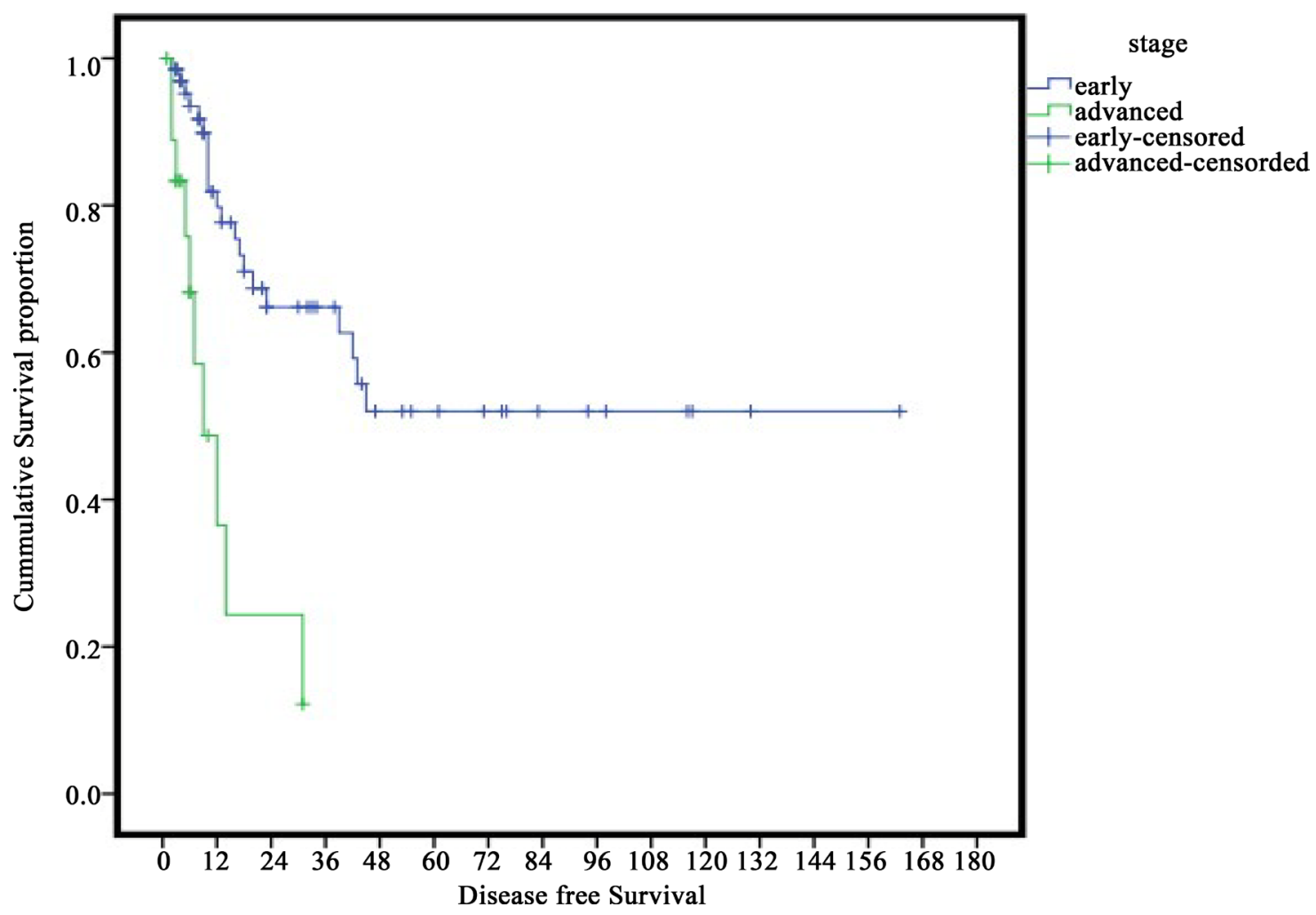

Figure 3. Impact of FIGO stage on disease free survival. 


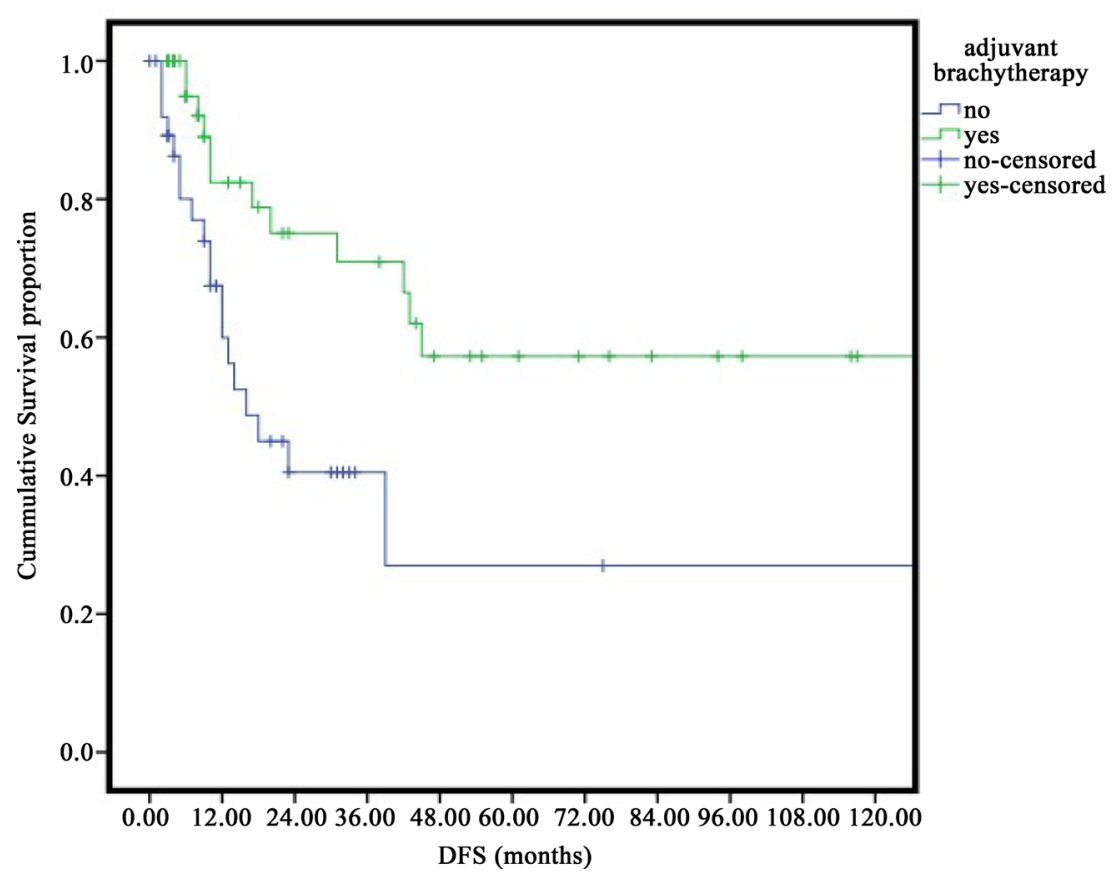

Figure 4. Impact of adjuvant brachytherapy on disease free survival.

Table 3. Overall Survival and different prognostic factors.

\begin{tabular}{|c|c|c|c|c|c|}
\hline Factors & No. of patient & 3 years OS\% & 5 years OS\% & P value (univariate) & P value (multivariate) \\
\hline \multicolumn{6}{|l|}{ Age (years) } \\
\hline$<60$ & 32 & 84.8 & 84.8 & \multirow[t]{2}{*}{0.020} & \\
\hline$\geq 60$ & 59 & 66.7 & 60.1 & & \\
\hline \multicolumn{6}{|l|}{ Pretreatment } \\
\hline Hemoglobin & & & & \multirow{3}{*}{0.009} & \\
\hline$<12 \mathrm{mg} / \mathrm{dl}$ & 31 & 62.5 & 41.7 & & \\
\hline$\geq 12 \mathrm{mg} / \mathrm{dl}$ & 17 & 100 & 100 & & \\
\hline \multicolumn{6}{|l|}{ Pathology } \\
\hline Papillary Serous & 30 & 85.7 & 85.7 & \multirow{4}{*}{0.341} & \\
\hline Clear Cell & 12 & 71.1 & 71.1 & & \\
\hline Undifferentiated & 8 & 85.7 & 85.7 & & \\
\hline Carcinosarcoma & 41 & 73.4 & 58.7 & & \\
\hline \multicolumn{6}{|l|}{ Lymph node status } \\
\hline $\mathrm{Nx}$ & 66 & 81.4 & 76 & \multirow{3}{*}{0.154} & \\
\hline No & 18 & 72.2 & 54.1 & & \\
\hline $\mathrm{N}+\mathrm{ve}$ & 7 & 68.6 & 0 & & \\
\hline \multicolumn{6}{|l|}{ FIGO stage } \\
\hline Early (I,II) & 68 & 84.9 & 75.1 & \multirow{2}{*}{0.004} & \multirow{5}{*}{0.041} \\
\hline Advanced (III,IV) & 23 & 34.9 & 0 & & \\
\hline \multirow{4}{*}{\multicolumn{6}{|c|}{$\begin{array}{c}\text { Adjuvant EBRT } \\
\text { No } \\
\text { Yes } \\
\text { Brachytherapy }\end{array}$}} \\
\hline & & & & & \\
\hline & & & & & \\
\hline & & & & & \\
\hline Yes & 49 & 77.7 & 72.5 & \multirow[t]{2}{*}{0.838} & \\
\hline No & 42 & 78.7 & 59.0 & & \\
\hline \multicolumn{6}{|l|}{ Chemotherapy } \\
\hline Yes & 9 & 85.7 & 85.7 & \multirow[t]{2}{*}{0.467} & \\
\hline No & 80 & 77.0 & 66.9 & & \\
\hline \multicolumn{6}{|c|}{ Duration from surgery to ERBT } \\
\hline$\leq 8$ weeks & 48 & 92.9 & 82.5 & \multirow[t]{2}{*}{0.011} & \multirow[t]{2}{*}{0.011} \\
\hline$>8$ weeks & 32 & 60.6 & 48.5 & & \\
\hline \multicolumn{6}{|c|}{ Overall Treatment Period (OAP) } \\
\hline$\leq 8$ weeks & 42 & 76.4 & 50.9 & \multirow[t]{2}{*}{0.250} & \\
\hline$>8$ weeks & 49 & 80.2 & 74.8 & & \\
\hline
\end{tabular}




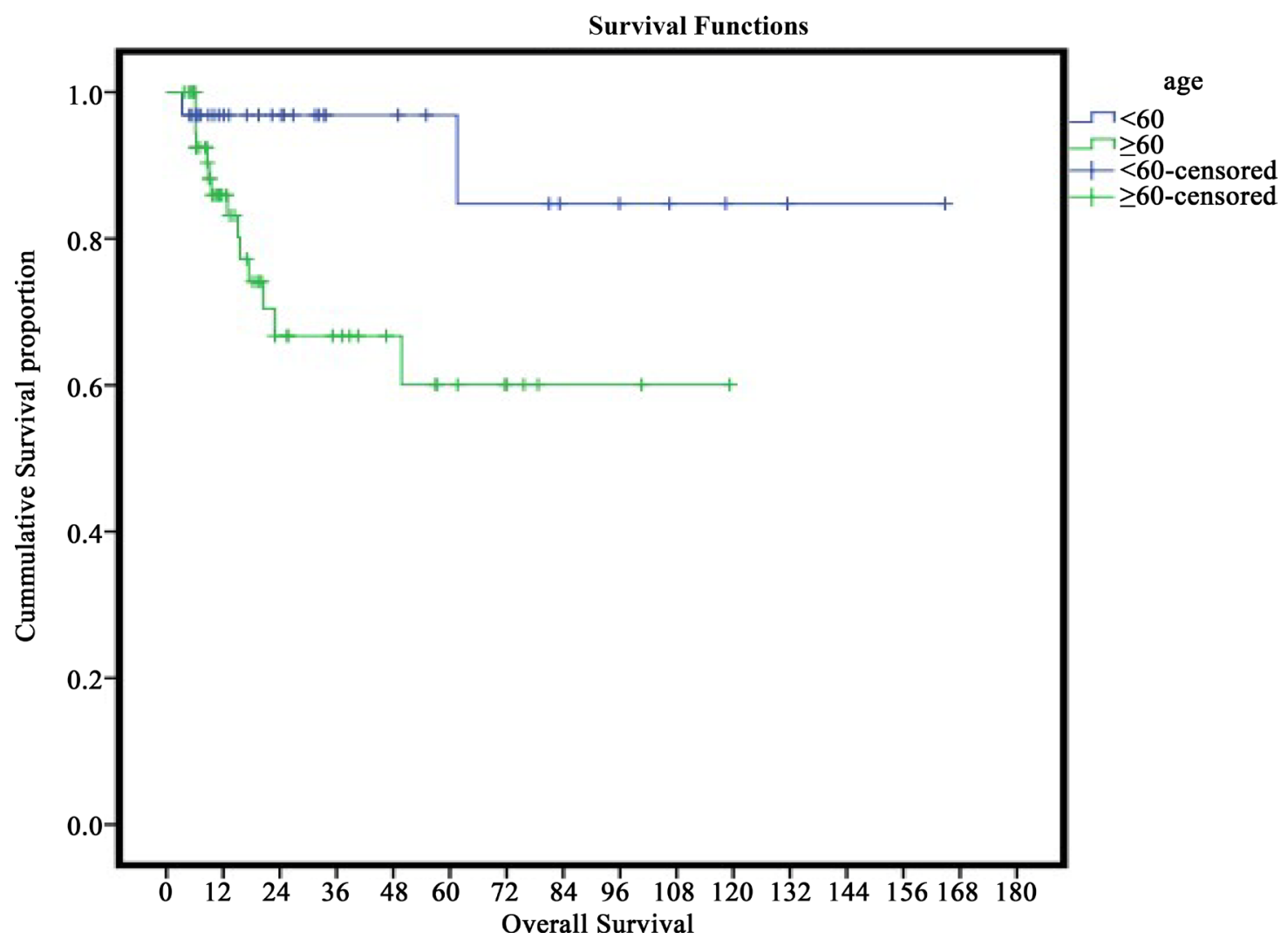

Figure 5. Impact of age on overall survival.

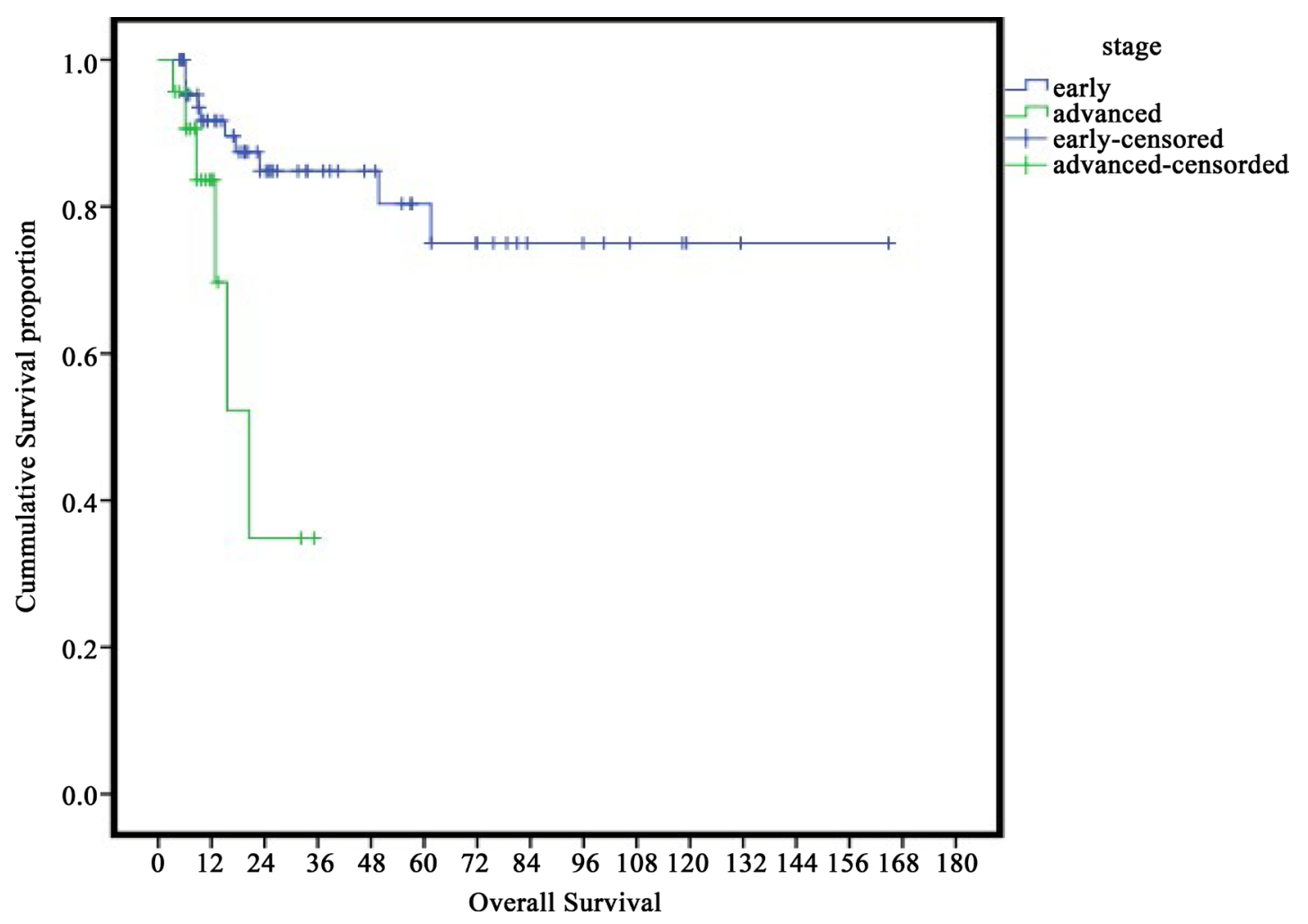

Figure 6. Impact of FIGO stage on overall survival. 
patients in the current study received adjuvant brachytherapy as a boost after ending EBRT. The use of brachytherapy was associated with significantly improved DFS ( $p$ value $=0.011)$ and a trend towards improved LC rates ( $\mathrm{p}$ value $=0.075$ ) but with no improvement in OS ( $\mathrm{p}$ value $=0.838)$.

The current study also showed that increasing the time interval between surgery and start of EBRT ( $>8$ weeks) had a negative impact on OS ( $p=0.011)$ which was also confirmed on multivariate analysis. This came close to the study done by Cattaneo et al. in which interval $>9$ weeks was associated with poor survival outcomes [17].

Regarding the sites of locoregional recuuence, our study found that the vaginal vault was the most common (50\%), followed by the pelvic region (22\%). This is matching with the results of the study by Demiral et al. in which $46.7 \%$ recurred in the vaginal stump and $33.3 \%$ in the pelvis [18].

Our study found that the most frequent site of distant failure was the peritoneum (24.1\%). This is most probably due to the fact that papillary serous and carcinosarcoma subtypes together represented the majority of our patients (78\%). These subtypes have a tendency for distant failure in the abdomen, which was confirmed in multiple studies and reviews [19] [20].

\section{References}

[1] Global Cancer Atlas-Globocan-2012. http://globocan.iarc.fr/Pages/fact_sheets_cancer.aspx

[2] Albertini, A.F., Devouassoux-Shisheboran, M., Genestie, C., et al. (2012) Pathology of Endometrioid Carcinoma. Bull Cancer, 99, 7-12.

[3] Hamilton, C.A., Cheung, M.K., Osann, K., Chen, L., Teng, N.N., Longacre, T.A., et al. (2006) Uterine Papillary Serous and Clear Cell Carcinomas Predict for Poorer Survival Compared to Grade 3 Endometrioid Corpus Cancers. British Journal of Cancer, 94, 642-646. http://dx.doi.org/10.1038/sj.bjc.6603012

[4] Mendivil, A., Schuler, K.M. and Gehrig, P.A. (2009) Non-Endometrioid Adenocarcinoma of the Uterine Corpus: A Review of Selected Histological Subtypes. Cancer Control, 16, 46-52.

[5] Dunton, C.J., Balsara, G., McFarland, M. and Hernandez, E. (1991) Uterine Papillary Serous Carcinoma: A Review. Obstetrical \& Gynecological Survey, 46, 97-102. http://dx.doi.org/10.1097/00006254-199102000-00014

[6] Fader, A.N., Starks, D., Gehrig, P.A., Secord, A.A., Frasure, H.E., O’Malley, D.M., et al. (2009) An Updated Clinicopathologic Study of Early-Stage Uterine Papillary Serous Carcinoma (UPSC). Gynecological Oncology, 115, $244-248$. http://dx.doi.org/10.1016/j.ygyno.2009.07.030

[7] Hamilton, C.A., Cheung, M.K., Osann, K., Chen, L., Teng, N.N., Longacre, T.A., et al. (2006) Uterine Papillary Serous and Clear Cell Carcinomas Predict for Poorer Survival Compared to Grade 3 Endometrioid Corpus Cancers. British Journal of Cancer, 94, 642-646. http://dx.doi.org/10.1038/sj.bjc.6603012

[8] Cirisano Jr., F.D., Robboy, S.J., Dodge, R.K., Bentley, R.C., Krigman, H.R., Synan, I.S., et al. (1999) Epidemiologic and Surgicopathologic Findings of Papillary Serous and Clear Cell Endometrial Cancers When Compared to Endometrioid Carcinoma. Gynecologic Oncology, 74, 385-394. http://dx.doi.org/10.1006/gyno.1999.5505

[9] Petignat, P., Usel, M., Gauthier, P., Popowski, Y., Pelte, M.F., Bouchardy, C., et al. (2008) Outcome of Uterine Clear Cell Carcinomas Compared to Endometrioid Carcinomas and Poorly-Differentiated Endometrioid Carcinomas. European Journal of Gynaecological Oncology, 29, 57-60.

[10] Sagr, E.R., Denschlag, D., Kerim-Dikeni, A., Stanimir, G., Gitsch, G. and Gilbert, L. (2007) Prognostic Factors and Treatment-Related Outcome in Patients with Uterine Papillary Serous Carcinoma. Anti-Cancer Research, 27, 12131217.

[11] Boruta 2nd, D.M., Gehrig, P.A., Fader, A.N., Olawaiye, A.B., et al. (2009) Management of Women with Uterine Papillary Serous Cancer: A Society of Gynecologic Oncology (SGO) Review. Gynecologic Oncology, 115, 142-153. http://dx.doi.org/10.1016/j.ygyno.2009.06.011

[12] Mendivil, A., Schuler, K.M. and Gehrig, P.A. (2009) Non-Endometrioid Adenocarcinoma of the Uterine Corpus: A Review of Selected Histological Subtypes. Cancer Control, 16, 46-52.

[13] Vance, S., Yechieli, R., Cogan, C., et al. (2012) The Prognostic Significance of Age in Surgically Staged Patients with Type II Endometrial Carcinoma. Gynecologic Oncology, 126, 16-19. http://dx.doi.org/10.1016/j.ygyno.2012.04.011

[14] Creasman, W.T., Odicino, F., Maisonneuve, P., et al. (2006) Carcinoma of the Corpus Uteri. FIGO 26th Annual Report on the Results of Treatment in Gynecological Cancer. International Journal of Gynaecology Obstetrics, 95, S105-S143. http://dx.doi.org/10.1016/s0020-7292(06)60031-3

[15] Harkenrider, M.M., Block, A.M., Siddiqui, Z.A., et al. (2015) The Role of Vaginal Cuff Brachytherapy in Endometrial Cancer. Gynecol Oncol. Gynecologic Oncology, 136, 365-372. http://dx.doi.org/10.1016/j.ygyno.2014.12.036

[16] Sorbe, B., Nordström, B., Mäenpää, J., et al. (2009) Intravaginal Brachytherapy in FIGO Stage I Low-Risk Endometri- 
al Cancer: A Controlled Randomized Study. International Journal of Gynecological Cancer, 19, 873-878. http://dx.doi.org/10.1111/igc.0b013e3181a6c9df

[17] Cattaneo 2nd, R., Hanna, R.K., Jacobsen, G., et al. (2014) Interval between Hysterectomy and Start of Radiation Treatment Is Predictive of Recurrence in Patients with Endometrial Carcinoma. International Journal of Radiation Oncology*Biology*Physics, 88, 866-871. http://dx.doi.org/10.1016/j.ijrobp.2013.11.247

[18] Demiral, S., Beyzadeoglu, M., Sager, O., et al. (2014) Evaluation of Treatment Outcomes of Early-Stage Endometrial Cancer Radiotherapy: A Single Center Experience. Asian Pacific Journal of Cancer Prevention, 15, 9599-9602. http://dx.doi.org/10.7314/APJCP.2014.15.22.9599

[19] Fader, A.N., Boruta, D., Olawaiye, A.B., et al. (2010) Uterine Papillary Serous Carcinoma: Epidemiology, Pathogenesis and Management. Current Opinion in Obstetrics and Gynecology, 22, 21-29. http://dx.doi.org/10.1097/gco.0b013e328334d8a3

[20] Galaal, K., Al Moundhri, M., Bryant, A., et al. (2014) Adjuvant Chemotherapy for Advanced Endometrial Cancer. Cochrane Database of Systematic Reviews, 5, CD0100680 http://dx.doi.org/10.1002/14651858.cd010681.pub2

\section{Submit or recommend next manuscript to SCIRP and we will provide best service for you:}

Accepting pre-submission inquiries through Email, Facebook, LinkedIn, Twitter, etc. A wide selection of journals (inclusive of 9 subjects, more than 200 journals)

Providing 24-hour high-quality service

User-friendly online submission system

Fair and swift peer-review system

Efficient typesetting and proofreading procedure

Display of the result of downloads and visits, as well as the number of cited articles

Maximum dissemination of your research work

Submit your manuscript at: http://papersubmission.scirp.org/ 